\title{
Metal and metalloid bioaccumulation in the Pacific blue shrimp Litopenaeus stylirostris (Stimpson) from New Caledonia: Laboratory and field studies
}

\author{
Marc Metian ${ }^{\mathrm{a}, \mathrm{b}}$, Laetitia Hédouin ${ }^{\mathrm{a}, \mathrm{c}}$, Mohamed M. Eltayeb ${ }^{\mathrm{d}}$, Thomas Lacoue-Labarthe ${ }^{\mathrm{b}}$, Jean-Louis \\ Teyssié $^{a}$, Chantal Mugnier ${ }^{e}$, Paco Bustamante ${ }^{b}$ and Michel Warnau ${ }^{a, b, *}$
}

\author{
a International Atomic Energy Agency - Marine Environment Laboratories (IAEA-MEL), 4 Quai Antoine ler, MC- \\ 98000 , Principality of Monaco, Monaco \\ ${ }^{\mathrm{b}}$ Littoral, Environnement et Sociétés (LIENSs), UMR 6250, CNRS-Université de La Rochelle, 2 rue Olympe de \\ Gouges, F-17042 La Rochelle Cedex 01, France \\ ${ }^{c}$ IRD-Centre de Nouméa, BP A5, 98848 Nouméa Cedex, New Caledonia \\ d IUCN - West Asia/Middle East (WAME), PO Box 1358, Jeddah 21431, Saudi Arabia \\ e Laboratoire d'Aquaculture de Calédonie, IFREMER BP 2059, 98846 Noumea Cedex, New Caledonia
}

*: Corresponding author : Michel Warnau, Tel.: +33 6625383 27, email address : warnaumichel@yahoo.com

\begin{abstract}
:
The present work aimed at better understanding metal and metalloid bioaccumulation in the edible Pacific blue shrimp Litopenaeus stylirostris, using both laboratory and field approaches. In the laboratory, the bioaccumulation kinetics of $\mathrm{Ag}, \mathrm{Cd}, \mathrm{Co}, \mathrm{Cr}$, and $\mathrm{Zn}$ have been investigated in shrimp exposed via seawater and food, using the corresponding y-emitting radiotracers $\left({ }^{110 \mathrm{~m}} \mathrm{Ag},{ }^{109} \mathrm{Cd},{ }^{57} \mathrm{Co}\right.$, ${ }^{51} \mathrm{Cr}$, and ${ }^{65} \mathrm{Zn}$ ) and highly sensitive nuclear detection techniques. Results showed that hepatopancreas and intestine concentrated the metals to the highest extent among the blue shrimp organs and tissues. Moulting was found to play a non negligible detoxification role for $\mathrm{Co}, \mathrm{Cr}$ and, to a lesser extent, $\mathrm{Zn}$. Metal retention by $L$. stylirostris widely varied (from a few days to several months), according to the element and exposure pathway considered (a given metal was usually less strongly retained when ingested with food than when it was taken up from the dissolved phase). In the field study, $\mathrm{Ag}, \mathrm{As}, \mathrm{Cd}, \mathrm{Co}, \mathrm{Cr}, \mathrm{Cu}, \mathrm{Mn}, \mathrm{Ni}$, and $\mathrm{Zn}$ were analysed in shrimp collected from a New Caledonian aquaculture pond. Metal concentrations in the shrimp muscles were generally relatively low and results confirmed the role played by the digestive organs and tissues in the bioaccumulation/storage/detoxification of metals in the Pacific blue shrimp. Preliminary risk considerations indicate that consumption of the shrimp farmed in New Caledonia is not of particular concern for human health.
\end{abstract}

Keywords: Crustacean; Metals; Biokinetics; Radiotracers; Moulting; Contamination 


\section{Introduction}

In many countries, shrimp is one of the most consumed seafood and wild-caught stocks are heavily fished (e.g., Cascorbi, 2007). While most species show no clear signs of overfishing, shrimp are believed to be exploited at or near their maximum sustainable yield (Cascorbi, 2007). Alternatively, shrimp culture has been adopted and consolidated as one of the largest profitable aquaculture activities all over the world (it has e.g. the most important commodity traded in value terms; FAO, 2007). Since 1997, the aquaculture shrimp production shows a strong expansion with an increase of $165 \%$ (viz., a $15 \%$ annual growth, FAO, 2007).

Among the shrimp species that are cultured, the Pacific blue shrimp Litopenaeus stylirostris, which is originally from the Pacific coast of Latin America, is well reared in the South Pacific region, especially in New Caledonia. This Overseas French Territory is the first world aquaculture producer of L. stylirostris with 2278 tonnes produced in 2006 (FAO, 2008), of which more than the half is exported. Indeed, in $2005,73 \%$ of the production was exported to France, Japan and Australia, and represented the second major export of the country (GFA, 2006).

New Caledonia is also known for another natural wealth: its nickel resources. Indeed, the largest resources of $\mathrm{Ni}$ laterites in the world (20-25\%) are found in the soils of New Caledonia, which have been largely exploited for more than a century (Dalvi et al., 2004). Nowadays, mining activities constitute the major economical resource of the Territory, which is the third world largest producer of nickel. Obviously, open-cast mining exploitations result in a considerably increased discharge of metals into the lagoon waters either directly or indirectly (via e.g. deforestation and enhanced soil erosion). This input threatens and damages the coastal ecosystems, local biodiversity, and quality of local seafood (Labrosse et al., 2000; 
Hédouin et al., 2007; Labonne et al., 2008; Metian et al., 2008a; Chouvelon et al., 2009). Mining-originating metal contamination is due essentially to $\mathrm{Ni}$ and the main mining byproducts occurring at elevated concentrations in $\mathrm{Ni}$ ores, such as $\mathrm{Co}, \mathrm{Cr}$ and $\mathrm{Mn}$ (Metian et al., 2008a,b).

Metal-enriched soils are obviously also a potential non negligible contamination source for shrimp ponds which are located near the coast (Mugnier et al., 2001). However, to the best of our knowledge, there are few studies available in the open literature that have investigated metal levels in the blue shrimp L. stylirostris (see e.g., Paez-Osuna and RuizFernandez, 1995a; Frías-Espericueta et al., 2007). Among them, only one considered the New Caledonian blue shrimp with a focus on the risk linked to its consumption (Chouvelon et al., 2009).

Therefore the aim of this study was to investigate the bioaccumulation and tissue distribution of a range of elements in the shrimp L. stylirostris, using both laboratory experiments under controlled conditions and in situ investigations. For this purpose, the bioaccumulation kinetics and body distribution of five selected radiotracers $\left({ }^{110 \mathrm{~m}} \mathrm{Ag},{ }^{109} \mathrm{Cd}\right.$, ${ }^{57} \mathrm{Co},{ }^{51} \mathrm{Cr}$, and ${ }^{65} \mathrm{Zn}$ ) were determined in the blue shrimp experimentally exposed to the metal radiotracers via seawater and their food. In the field study, eight metals $(\mathrm{Ag}, \mathrm{Cd}, \mathrm{Co}, \mathrm{Cr}, \mathrm{Cu}$, $\mathrm{Mn}, \mathrm{Ni}$, and $\mathrm{Zn}$ ) and one metalloid (As) were analysed in the tissues of L. stylirostris from an aquaculture farm to assess their levels and the human risk related to shrimp consumption.

\section{Materials and Methods}

\subsection{Radiotracer experiments in the laboratory.}

\subsubsection{Origin and acclimation of organisms}


A batch of approximately 100 Litopenaeus stylirostris (Stimpson, 1874) was obtained from the Ifremer experimental farm (Station d'Aquaculture Ifremer de Saint-Vincent, New Caledonia) in January 2002 and shipped to MEL premises in Monaco. Prior to experimentation shrimp were acclimated for 2 months to laboratory conditions (open circuit 400-1 aquarium; $0.45-\mu \mathrm{m}$ filtered water renewal: $40 \mathrm{l} \mathrm{h}^{-1}$; salinity: 36 p.s.u.; temperature: $25 \pm$ $0.5^{\circ} \mathrm{C} ; \mathrm{pH}: 8.0 \pm 0.1 ;$ light/dark cycle: $12 \mathrm{~h} / 12 \mathrm{~h}$ ) simulating the conditions prevailing in pond waters where shrimp are reared. During acclimation, shrimp were fed daily pre-cooked mussels. Recorded mortality was lower than $3 \%$.

Forty penaeids of similar size and weight $(7.2 \pm 1.1 \mathrm{~g}$ wet $\mathrm{wt})$ were then collected and divided in two groups of 20 individuals. Each group was placed in a 70-1 glass aquarium (0.45- $\mu \mathrm{m}$ filtered water; constant aeration; salinity: 36 p.s.u.; temperature: $25 \pm 0.5^{\circ} \mathrm{C}$; $\mathrm{pH}$ : $8.0 \pm 0.1 ;$ light/dark cycle: $12 \mathrm{~h} / 12 \mathrm{~h}$; open $v s$. close circuit as indicated below) in which the experiments were conducted (see below). In order to avoid cannibalism (e.g. during moulting) and to facilitate individual recognition, during the whole duration of the experiments, each shrimp was kept individually in a cylindrical PVC container $(160 \mathrm{~mm}$ height $\times 80 \mathrm{~mm}$ diameter) covered above and below with $300-\mu \mathrm{m}$ mesh size net (to allow for free water circulation).

\subsubsection{Exposure via seawater}

A 24-d radiotracer exposure was carried out to determine the uptake kinetics of dissolved metals in L. stylirostris. Physico-chemical parameters of the seawater (salinity, temperature and $\mathrm{pH}$ ) were checked twice daily all along the experiment duration. The selected metals $(\mathrm{Ag}, \mathrm{Cd}, \mathrm{Co}, \mathrm{Cr}, \mathrm{Zn})$ were introduced into the experimental microcosm as high 
specific activity radiotracers purchased from Amersham, UK $\left({ }^{109} \mathrm{Cd}\right.$ as $\mathrm{CdCl}_{2}$ in $0.1 \mathrm{M} \mathrm{HCl}$, $\mathrm{T}_{1 / 2}=426.6 \mathrm{~d}$ and ${ }^{51} \mathrm{Cr}$ as $\mathrm{Na}_{2} \mathrm{CrO}_{4}$ in saline solution, $\left.\mathrm{T}_{1 / 2}=27.7 \mathrm{~d}\right), \mathrm{CERCA}$, France $\left({ }^{110 \mathrm{~m}} \mathrm{Ag}\right.$ as $\mathrm{AgNO}_{3}$ in $1 \mathrm{M} \mathrm{HNO}_{3}, \mathrm{~T}_{1 / 2}=249.8 \mathrm{~d}$ and ${ }^{57} \mathrm{Co}$ as $\mathrm{CoCl}_{2}$ in $0.1 \mathrm{M} \mathrm{HCl}, \mathrm{T}_{1 / 2}=271.8 \mathrm{~d}$ ), and Isotope Product Lab., USA ( ${ }^{65} \mathrm{Zn}$ as $\mathrm{ZnCl}_{2}$ in $0.5 \mathrm{M} \mathrm{HCl}, \mathrm{T}_{1 / 2}=243.9 \mathrm{~d}$ ). Seawater was spiked with a low nominal activity of each selected radiotracer: $0.5 \mathrm{kBq} 1^{-1}\left({ }^{110 \mathrm{~m}} \mathrm{Ag},{ }^{57} \mathrm{Co},{ }^{65} \mathrm{Zn}\right), 1$ $\mathrm{kBq}^{-1}\left({ }^{51} \mathrm{Cr}\right)$ and $1.5 \mathrm{kBq}^{-1}\left({ }^{109} \mathrm{Cd}\right)$. In term of stable metal concentration, these additions corresponded to $\mathrm{Ag}\left(19 \mathrm{pmol}^{-1}\right), \mathrm{Cd}\left(0.7 \mathrm{pmol}^{-1}\right), \mathrm{Co}\left(0.5 \mathrm{pmol} \mathrm{l}^{-1}\right), \mathrm{Cr}\left(2.9 \mathrm{pmol} \mathrm{l}^{-1}\right)$ and $\mathrm{Zn}$ $\left(92 \mathrm{pmol} \mathrm{l}^{-1}\right.$ ), i.e. activities that are 1 to 3 orders of magnitude lower than the background concentrations of these metals in open seas (Bruland, 1983). No change in pH was detectable in the aquarium (close circuit) after tracer addition. Seawater and spikes were renewed daily for $5 \mathrm{~d}$, then every second day in order to keep exposure activities constant (Hédouin et al., 2006). Activity of the metal tracers in seawater was checked daily, before and after each seawater renewal, to determine time-integrated activities (Warnau et al., 1996a; Rodriguez y Baena et al., 2006a). For the entire experimental time course, the time-integrated tracer activities in seawater were $0.46 \mathrm{kBq}^{110 \mathrm{~m}} \mathrm{Ag} \mathrm{l}^{-1}, 1.56 \mathrm{kBq}^{109} \mathrm{Cd} \mathrm{l}^{-1}, 0.56 \mathrm{kBq}^{57} \mathrm{Co}^{-1}, 1.27 \mathrm{kBq}$ ${ }^{51} \mathrm{Cr} \mathrm{l}^{-1}$, and $0.46 \mathrm{kBq}{ }^{65} \mathrm{Zn}^{-1}$. Shrimp were fed briefly (30 min) before each seawater and spike renewal in clean seawater so as to avoid any possible ingestion of radiotracer through the food. Shrimp were individually and periodically $\gamma$-counted alive over the 24-d exposure period to determine the radiotracer uptake biokinetics (Warnau and Bustamante, 2007).

At the end of the exposure period, the 20 blue shrimp were carefully transferred to another 70-1 aquarium supplied with natural flowing seawater (open circuit; water renewal: 40 $\left.1 \mathrm{~h}^{-1}\right)$. They were fed daily and were periodically $\gamma$-counted to follow the radiotracer depuration kinetics over 43 d. After 4 and 43 d, 3 individuals were dissected: the abdominal exoskeleton, the abdominal muscle, the cephalothorax, the hepatopancreas and the intestine 
were separated, weighed (wet wt) and radioanalysed to determine the radiotracer body distribution.

When an ecdysis event occurred during the experiment, the exuvia was immediately removed from the PVC container, carefully rinsed with clean filtered seawater, weighed, and $\gamma$-counted.

\subsubsection{Exposure via the food}

Preparation of the radiolabelled food was carried out by exposing for 3 weeks commercial mussels (Mytilus edulis) via natural seawater spiked with the radiotracers: 0.5 $\mathrm{kBq}^{-1}\left({ }^{110 \mathrm{~m}} \mathrm{Ag},{ }^{57} \mathrm{Co},{ }^{65} \mathrm{Zn}\right), 1 \mathrm{kBq} \mathrm{l} \mathrm{l}^{-1}\left({ }^{51} \mathrm{Cr}\right)$ and $1.5 \mathrm{kBq} \mathrm{l}^{-1}\left({ }^{109} \mathrm{Cd}\right)$ (Boudjenoun et al., 2007).

The 20 shrimp placed in the 70-1 glass aquarium (open circuit; water renewal: $401 \mathrm{~h}^{-1}$ ) were each provided with one radiolabelled mussel that was introduced in each PVC container. Shrimp were allowed feeding on the mussel for $3 \mathrm{~h}$ (pulse-chase feeding method; see e.g. Warnau et al., 1996a; Metian et al., 2008c). In parallel, a group of 3 additional shrimp was placed in the same aquarium in 3 additional PVC containers and fed uncontaminated mussels. These individuals were used as a control for any possible radiotracer recycling from seawater due to radiotracer leaching from the contaminated food or, later on, from shrimp depuration. At the end of the feeding period, each shrimp (including the control ones) was whole-body $\gamma$ counted alive. From then onwards, organisms were regularly radioanalysed to follow the radiotracer depuration kinetics over 39 d. After 39 d of depuration, 3 individuals were dissected to determine the body distribution of the radiotracers. As for seawater experiment, when moulting events did occur, exuviae were immediately removed to be radioanalysed.

\subsubsection{Radioanalysis}


Radioactivity was measured using a high-resolution $\gamma$-spectrometer system composed of three Germanium -N or P type- detectors (EGNC 33-195-R, Eurysis ${ }^{\circledR}$ ) connected to a multi-channel analyzer and a computer equipped with a spectra analysis software (Interwinner $^{\circledR} 6$ ). The radioactivity was determined by comparison with standards of known activity and of appropriate geometry. Measurements were corrected for counting efficiency and physical radioactive decay. Counting time was adjusted to obtain propagated counting errors less than 5\% (Rodriguez y Baena et al., 2006b). Counting times usually ranged from 10 to $20 \mathrm{~min}$ for the radioanalysis of living organisms.

\subsection{Metals in organisms from the field}

\subsubsection{Trace element analysis}

Twelve L. stylirostris were collected in the ponds of the "Station d'Aquaculture Ifremer de Saint-Vincent" in March 2005. Each individual was rinsed thrice with seawater to remove sediment and other particles, weighed $(5.3 \pm 1.2 \mathrm{~g}$ wet $\mathrm{wt})$ and then dissected to separate exoskeleton (abdominal exoskeleton including pleiopods and tail), muscle (abdominal muscle), cephalothorax, hepatopancreas, and intestine. All tissue samples were dried at $60^{\circ} \mathrm{C}$ until reaching a constant weight, ground to powder and digested according to the method described in Hédouin et al. (2008). Elements were then analysed using a Varian ${ }^{\circledR}$ Vista-Pro ICP-OES (As, Cr, Cu, Mn, Ni, and Zn) or a Varian ${ }^{\circledR}$ ICP-MS Ultra Mass 700 (Ag, Cd and Co). Measurements of Certified Reference Materials (dogfish liver DOLT-3, NRCC, and lobster hepatopancreas TORT-2, NRCC) were in good agreement with the certified values given and indicated the following recoveries (in \%): 103 (Ag), 98 (As), 103 (Cd), 112 
(Co), $79(\mathrm{Cr}), 95(\mathrm{Cu}), 84(\mathrm{Mn}), 113(\mathrm{Ni})$, ands $106(\mathrm{Zn})$. The detection limits $\left(\mu \mathrm{g} \mathrm{g}{ }^{-1}\right.$ dry wt) were $10.1(\mathrm{As}), 0.8(\mathrm{Cr}), 0.5(\mathrm{Cu}), 0.04(\mathrm{Mn}), 1.1(\mathrm{Ni})$ and $0.7(\mathrm{Zn})$ for ICP-OES and 0.1 $(\mathrm{Ag}), 0.3(\mathrm{Cd})$ and $0.03(\mathrm{Co})$ for ICP-MS. Mean element concentrations are given on a dry weight basis ( $\mu \mathrm{g} \mathrm{g}^{-1}$ dry wt).

\subsubsection{Preliminary risk assessment for consumers}

From the element levels measured in the shrimp muscles, a recommended maximum number of shrimp to be consumed was assessed on the basis of the Provisional Maximum Tolerable Daily Intake (PMTDI) and Provisional Tolerable Weekly Intake (PTWI) given by WHO (1989) and by the Joint Expert Committee on Food Additives (JECFA, 2006, 2008). The computation method is described in Metian et al (2008a) and Chouvelon et al. (2009) and was carried out for $\mathrm{As}, \mathrm{Cd}, \mathrm{Cu}$ and $\mathrm{Zn}$ (for which a PMTDI or PTWI does exist), taking into account abdominal muscle, abdominal muscle + intestine or abdominal muscle + intestine + hepatopancreas (i.e., the three ways shrimp are eaten). PMTDI for $\mathrm{Cu}$ and $\mathrm{Zn}$ are 500 and $1,000 \mu \mathrm{g} \mathrm{kg}^{-1}$ human body weight $\mathrm{d}^{-1}$, respectively and PTWI for As and Cd are 15 and $7 \mu \mathrm{g}$ $\mathrm{kg}^{-1}$ human body weight $\mathrm{wk}^{-1}$, respectively.

\subsection{Data treatment}

Whole-body uptake and depuration kinetics of the seawater and feeding exposure experiments were fitted using the kinetic models, nonlinear regression routines and iterative adjustment (Statistica ${ }^{\circledR}$ 6), and statistical methods as described by Warnau et al. (1996a,b) and Metian et al. (2007). 
Statistical analyses of the field data regarding metal and metalloid concentrations in the shrimp were performed by one-way ANOVA, followed by the multiple comparison test of Tukey (Zar, 1996).

The level of significance for statistical analyses was always set at $\alpha=0.05$.

\section{Results}

\subsection{Radiotracers experiment:}

\subsubsection{Exposure via seawater}

The bioaccumulation kinetics of ${ }^{57} \mathrm{Co},{ }^{51} \mathrm{Cr}$, and ${ }^{65} \mathrm{Zn}$ in whole-body L. stylirostris were best described by a first-order saturation model whereas bioaccumulation of ${ }^{110 \mathrm{~m}} \mathrm{Ag}$ and ${ }^{109} \mathrm{Cd}$ was best fitted by a linear model (Fig. 1, Table 1). The values estimated for the uptake rate constant, $\mathrm{k}_{\mathrm{u}}$, allowed ranking the radiotracers according to the following order of initial uptake efficiency: ${ }^{65} \mathrm{Zn}>{ }^{110 \mathrm{~m}} \mathrm{Ag}>{ }^{57} \mathrm{Co}>{ }^{109} \mathrm{Cd}>{ }^{51} \mathrm{Cr}$ (Table 1) whereas the concentration factors observed at the end of the exposure period, $\mathrm{CF}_{24 \mathrm{~d}}$, ranked the elements according to the following order: ${ }^{110 \mathrm{~m}} \mathrm{Ag}>{ }^{65} \mathrm{Zn}>{ }^{109} \mathrm{Cd}>{ }^{57} \mathrm{Co}>{ }^{51} \mathrm{Cr}$.

When non-contaminating conditions were restored, the depuration kinetics of the 5

radiotracers were followed for $43 \mathrm{~d}$. The whole-body depuration of ${ }^{110 \mathrm{~m}} \mathrm{Ag}$ was best fitted by a single-component exponential model, whereas depuration kinetics of the 4 other radiotracers were best described by a double component exponential model (Fig. 1, Table 1). Estimated biological half-lives indicate that in terms of metal retention strength, the elements examined are ranked according to the following order: ${ }^{109} \mathrm{Cd}>{ }^{51} \mathrm{Cr}>{ }^{65} \mathrm{Zn} \approx{ }^{110 \mathrm{~m}} \mathrm{Ag} \approx{ }^{57} \mathrm{Co}$. 


\subsubsection{Exposure via the food}

During the food experiment, frequent monitoring of the control group of shrimp demonstrated that no significant secondary contamination from radiotracer recycling via seawater did occur over the entire observation period. Whole-body depuration kinetics of ${ }^{110 \mathrm{~m}} \mathrm{Ag}$ and ${ }^{57} \mathrm{Co}$ ingested with food (i.e. radiolabelled mussels) were best described by a single-component exponential model whereas depuration of ingested ${ }^{109} \mathrm{Cd},{ }^{51} \mathrm{Cr}$, and ${ }^{65} \mathrm{Zn}$ were best fitted by a double-component exponential model (Fig. 2, Table 1). Assimilation efficiency ( $\mathrm{AE}$; i.e. $\mathrm{A}_{01}$ ) of the radiotracers ingested with food was generally elevated ( $\mathrm{AE}>$ $38 \%$ ) whereas the biological half-life of the radiotracers was generally short, especially for ${ }^{110 \mathrm{~m}} \mathrm{Ag},{ }^{109} \mathrm{Cd}$ and ${ }^{57} \mathrm{Co}\left(\mathrm{T}_{\mathrm{b}^{1 / 2}}<11 \mathrm{~d}\right)($ Table 1$)$.

\subsubsection{Organotropism}

During the depuration phase of both seawater and feeding experiments, dissections were carried out in order to determine the metal distribution among selected body compartments of L. stylirostris at 4 and $43 \mathrm{~d}$ of depuration following the 24-d seawater exposure and at $39 \mathrm{~d}$ following the single radiolabelled feeding (Table 2). Because of the fast physical decay of ${ }^{51} \mathrm{Cr}$, this radiotracer was only detected at the first dissection time $\left(4^{\text {th }} \mathrm{d}\right.$ of seawater depuration). ${ }^{110 \mathrm{~m}} \mathrm{Ag}$ was always mainly distributed in the hepatopancreas (> 50\%) whereas ${ }^{65} \mathrm{Zn}$ was mainly occurring in both the abdominal muscle and hepatopancreas. Regarding ${ }^{109} \mathrm{Cd},{ }^{57} \mathrm{Co}$ and ${ }^{51} \mathrm{Cr}$, the body distribution at the $4^{\text {th }} \mathrm{d}$ of seawater depuration clearly showed a concurrent role of hepatopancreas and cephalothorax in element storage. Later on in the seawater depuration period, as well as at the end of the post-feeding depuration period, the cephalothorax became the predominant body compartment for ${ }^{109} \mathrm{Cd}(\geq$ 
$66 \%$ ) whereas ${ }^{57}$ Co was mainly distributed in the cephalothorax and the exoskeleton. Interestingly, body distributions at the end of seawater and feeding depuration period were found to be not significantly different from each other (Table 2).

In term of radiotracer activity concentration (Table 3), three compartments were found to display the highest values: hepatopancreas, intestine, and cephalothorax. The activity concentrations generally decreased significantly (up to one order of magnitude) in hepatopancreas and cephalothorax during the depuration after seawater exposure. In contrast, the activity concentrations in the intestine remained unchanged $\left({ }^{109} \mathrm{Cd}\right)$ or increased significantly $\left({ }^{110 \mathrm{~m}} \mathrm{Ag}\right.$ and $\left.{ }^{57} \mathrm{Co}\right)$ during the depuration phase (Table 3$)$.

\subsubsection{Element release during ecdysis}

No moulting events were observed during the metal exposure periods. In contrast, a total of 23 individuals moulted at 6 different times during the depuration phases ( 8 individuals in the seawater experiment and 15 in the feeding experiment). Except for ${ }^{110 \mathrm{~m}} \mathrm{Ag}$, metal proportions released with the exuviae were lower in the feeding experiment than in the seawater experiment. During seawater depuration, exuvia-associated ${ }^{51} \mathrm{Cr}$ and ${ }^{65} \mathrm{Zn}$ proportion tended to be somewhat higher during the first 2 weeks; the repartition of the other elements remained similar during the depuration phase. Considering all moulting events together, the proportion (average and range) of metal associated with the exuviae was: $0.4 \pm 0.4 \%(0.1$ $1.3 \%$ ) for ${ }^{110 \mathrm{~m}} \mathrm{Ag}, 2.4 \pm 1.5 \%(0.7-4.5 \%)$ for ${ }^{109} \mathrm{Cd}, 33 \pm 15 \%(17-52 \%)$ for ${ }^{57} \mathrm{Co}, 25 \pm 16 \%$ $(0.4-45 \%)$ for ${ }^{51} \mathrm{Cr}, 10 \pm 6 \%(1.5-19 \%)$ for ${ }^{65} \mathrm{Zn}$ during the seawater depuration phase $(\mathrm{n}=$ 8) and $0.7 \pm 0.8 \%(0.1-2.4 \%)$ for ${ }^{110 m} \mathrm{Ag}, 0.8 \pm 0.7 \%(0.2-2.6 \%)$ for ${ }^{109} \mathrm{Cd}, 6.9 \pm 3.6 \%(1.9-$ $14 \%$ ) for ${ }^{57} \mathrm{Co}, 13.1 \pm 5.4 \%(8-28 \%)$ for ${ }^{51} \mathrm{Cr}, 1.3 \pm 0.7 \%(0.2-2.9 \%)$ for ${ }^{65} \mathrm{Zn}$ during the feeding depuration phase $(n=15)$. 


\subsection{Field Study}

\subsubsection{Metal and metalloid analysis}

Arsenic and metal concentrations measured in the different body compartments of the shrimp collected from the Saint-Vincent aquaculture farm are given in Table 4. For all elements, hepatopancreas and/or intestine displayed the highest concentrations.

In terms of body burden distribution, the elements were distributed is a quite variable way among body compartments (Table 5). The only exception was Ag that was mainly (98\%) contained in the hepatopancreas. The abdominal muscle displayed the highest load of As and Zn (40 and 43\%). Cd was mainly (93\%) occurring in cephalothorax and hepatopancreas. Regarding $\mathrm{Co}, \mathrm{Cu}$ and $\mathrm{Mn}$, the major part of these metals (74-88\%) was localized in the exoskeleton and cephalothorax, whereas $\mathrm{Cr}$ and $\mathrm{Ni}$ were mainly distributed $(82-87 \%)$ in muscle and exoskeleton.

\subsubsection{Preliminary risk assessment}

The concentrations measured in the edible part (Table 4) allowed computing the number of shrimp that a human must eat to reach the PMTDI and PTWI of the elements for which such a parameter is provided, i.e. As, Cd, $\mathrm{Cu}$ and $\mathrm{Zn}$ (WHO, 1989; JECFA, 2006, 2008). Computations were realised with different sets of data corresponding to several combinations of body compartments in order to take into account all the parts that can be eaten according to the care with which the animal is decorticated (i.e., abdominal muscle 
alone and abdominal muscle + intestine) and the taste of the consumer (abdominal muscle + hepatopancreas and abdominal muscle + intestine + hepatopancreas).

Calculations indicated that the number of shrimp to be eaten to reach a contamination risk was always high (several hundreds to several thousands; data not shown). When considering abdominal muscle alone, the worst scenario was found to be As: a $50-\mathrm{kg}$ person should eat 195 shrimp a week (i.e. $3.84 \mu \mathrm{g}$ of total As) to reach the maximum recommended weekly intake. If abdominal muscle + intestine + hepatopancreas are considered, the same person should eat a slightly lower amount of shrimp per week (viz., $184 \mathrm{wk}^{-1}$ ).

\section{Discussion}

Metal releases resulting from the nickel mining industry and related activities are an environmental conservation issue of concern in New Caledonia (Labrosse et al., 2000; Labonne et al., 2008; Metian et al. 2008a).

Surprisingly, few information are available in the open literature regarding metal contamination in seafood from New Caledonia (see e.g., Labonne et al., 2008; Metian et al. 2008a; Chouvelon et al., 2009). In particular, besides the recent study of Chouvelon et al. (2009) very little has been published on the blue shrimp L. stylirostris, for which this country is the first world aquaculture producer (FAO, 2008). Moreover, to the best of our knowledge, studies that have investigated metals in L. stylirostris from other regions of the world were devoted to the measurement of metal concentrations in the main edible part (i.e. the abdominal muscle) (e.g. Paez-Osuna and Ruiz-Fernandez, 1995a; Frías-Espericueta et al., 2007). Hence, nothing is known regarding the behaviour of this shrimp towards metals occurring in different compartments of its environment (dissolved vs particulate metals). This information is however of great interest in the context of a cultivated organisms, as it could 
allow controlling -at least partly- the metal intake in the shrimp by regulating environmental parameters (water $v s$ added food quality).

Our work was carried out using both laboratory and field approaches. Laboratory experiments were designed to better understand the metal bioaccumulation capacity of the shrimp exposed via either the dissolved phase or its food. The field study was then carried out in order to establish a baseline for metal and metalloid levels in L. stylirostris organs and to assess the risk related to its consumption for humans.

Laboratory experiments have shown that L. stylirostris readily takes up $\mathrm{Ag}, \mathrm{Cd}, \mathrm{Co}$, $\mathrm{Cr}$ and $\mathrm{Zn}$ when dissolved in seawater. This was especially true for $\mathrm{Ag}$ and $\mathrm{Cd}$ which displayed linear uptake kinetics over the 24-d observation period, indicating that these two metals were still far from reaching steady-state equilibrium and can reach, over the longer term, concentration factors (CF) much higher than those observed here (80 and 20 for $\mathrm{Ag}$ and $\mathrm{Cd}$, respectively). The experiments also revealed that $\mathrm{Ag}, \mathrm{Cr}$ and $\mathrm{Zn}$ were retained in shrimp tissues with biological half-lives $\left(\mathrm{Tb}_{1 / 2}\right) \leq 35 \mathrm{~d}$, whereas $\mathrm{Cd}$ and Co were retained much more strongly $\left(\mathrm{Tb}_{1 / 2}: 796\right.$ and $152 \mathrm{~d}$, respectively).

Following a single-feeding exposure, $\mathrm{Ag}, \mathrm{Cd}$, and Co were efficiently assimilated from food $(\mathrm{AE}>77 \%)$ compared to $\mathrm{Cr}$ and $\mathrm{Zn}(\mathrm{AE}<54 \%)$. However, the $\mathrm{Tb}_{1 / 2}$ of these elements did not exceed $32 \mathrm{~d}$. To the best of our knowledge, trophic transfer of metals is not documented for L. stylirostris. However data on $\mathrm{Cd}$ and $\mathrm{Zn}$ have been published for other shrimp, such as Penaeus indicus (Nunez-Nogueira et al., 2006) and Palaemon spp (Wallace et al., 1998; Rainbow et al., 2006a,b). AEs estimated in L. stylirostris for Cd and Zn indicate that their values fall within those observed in the aforementioned shrimp species (i.e. 20 to 83\%). In addition, as it has been reported for P. indicus and Palaemon spp, our observations indicate that $\mathrm{Zn}$ is more efficiently assimilated by L. stylirostris than $\mathrm{Cd}$. 
Regarding the other metals, Ag is the only element whose trophic transfer has been previously investigated in another shrimp species (Rainbow et al., 2006a,b). The latter studies reported AE for Ag in Palaemon spp ranging between 33 and 50\%. Conversely, here we found an estimated $\mathrm{A}_{01}$ value of $100 \%$ for $\mathrm{Ag}$. This could mean that L. stylirostris would be able to assimilate the totality of $\mathrm{Ag}$ ingested with food (i.e., $\mathrm{AE}=\mathrm{A}_{01}=100 \%$ ). Such extreme assimilation efficiency has already been documented in some organisms (e.g., Rainbow, 2002; Luoma and Rainbow, 2005), such as in the sea star Asterias rubens (Temara et al. 1996; Warnau et al., 1999; Danis et al., 2004). In the sea star, the almost 100\% AE for Co is related to the particular feeding mode of the organism (Warnau et al., 1999): A. rubens has an extraoral digestion and ingests/swallows its prey as a pre-digested material, which makes internal assimilation extremely efficient (e.g., Jangoux, 1982). In the case of L. stylirostris, however, such particular feeding mode is lacking (Dall and Moriarty, 1983). In addition, observed $\mathrm{T}_{\mathrm{b} 1 / 2}$ was quite short $(11 \mathrm{~d})$ and the remaining activities measured in the body compartments $39 \mathrm{~d}$ after the feeding were very low (see Table 3). This suggests that the ingested Ag would remain in the digestive tract from where it could then be progressively eliminated along with the faeces rather than being entirely assimilated. Hence, the single exponential compartment that describes the depuration of dietary Ag in the Pacific blue shrimp would represent a shortlived compartment rather than a long-lived one. These observations regarding dietary Ag also suggest that the food pathway would be a minor route of contribution to the global Ag bioaccumulation in L. stylirostris. This could also explain why Ag concentrations measured in the shrimp muscles from the field were so low (see Table 4).

In invertebrates, and in crustaceans in particular, the digestive gland or hepatopancreas is well known to play an important role in metal accumulation and detoxification (e.g., Gibson \& Barker, 1979; Dall and Moriarty, 1983; Rainbow, 1998; Bianchini et al., 2007). Concentrations of $\mathrm{Cd}, \mathrm{Cu}, \mathrm{Mn}$ and $\mathrm{Zn}$ that we measured in the hepatopancreas of $L$. 
stylirostris from New Caledonia were approximately twice those reported for the same species from the Gulf of California (Ruelas-Inzunza and Paez-Osuna, 2004). Regarding Ag, As, $\mathrm{Cd}$, and $\mathrm{Co}$, we measured similar concentrations as those reported in the hepatopancreas of the black tiger shrimp Penaeus monodon from contaminated areas from South Vietnam (Tu et al., 2008). To the best of our knowledge, the concentrations in $\mathrm{Cd}, \mathrm{Cr}, \mathrm{Mn}$, and Ni that were found in the hepatopancreas of the New Caledonian L. stylirostris are among the highest reported for shrimp and even crustaceans (e.g., Eisler, 1981; Méndez et al., 2001, Tu et al., 2008).

In contrast to hepatopancreas, the intestine is not generally considered as a major bioaccumulator tissue for metals, although some authors have reported that the hindgut may play a significant role in the elimination or sequestration of several xenobiotics, including metals such as Ag, Al, Cd, Fe and Zn (e.g., Buchanan et al., 1984; Berthet et al., 1992; Bendell-Young, 1994; Warnau and Jangoux, 1999). In agreement, our results have shown that when L. stylirostris is exposed to metals and then placed in clean conditions, the concentrations of 3 elements significantly increased (Ag and Co) or remained unchanged $(\mathrm{Cd})$ in the shrimp intestine over the time. Overall, our dataset supports the assumption of a physiological strategy that tends to result in higher metal concentrations in the digestive organs (i.e. intestine and hepatopancreas) possibly through detoxification and/or storage mechanisms.

Following seawater or food exposures, $\mathrm{Cd}$, $\mathrm{Co}$ and $\mathrm{Cr}$ were mainly associated with the cephalothorax and $\mathrm{Zn}$ was mainly associated with both the cephalothorax and abdominal muscle. Metal and metalloid analyses carried out on the farmed Pacific blue shrimp confirmed that the cephalothorax contained a significant fraction of $\mathrm{As}, \mathrm{Cd}, \mathrm{Co}, \mathrm{Cu}, \mathrm{Mn}(28-57 \%$; see Table 5). This body compartment is composed of many sub-compartments that include, among other, gills and antennal glands, which are well known to play a significant role in 
metal bioaccumulation and depuration in decapods (e.g. Arruda-Freire and CampbellMcNamara, 1995; Paez-Osuna and Tron-Mayen, 1996; Rainbow, 1998). Obviously, cephalothorax is also composed to a large extent of exoskeleton. In this respect, our radiotracer experiments have shown that a significant fraction of $\mathrm{Co}, \mathrm{Cr}$ and $\mathrm{Zn}$ can be found associated with the exoskeleton (see Table 2) and then be eliminated from the organism during moulting (ecdysis). Such a process has already been observed in other crustaceans and is reported as a detoxification/metal excretion mechanism (e.g., Keteles and Fleeger, 2001; Rodriguez y Baena et al. 2006a, 2008). A significant metal fraction associated with the exoskeleton was also observed for $\mathrm{Co}, \mathrm{Cu}, \mathrm{Cr}, \mathrm{Mn}, \mathrm{Ni}$ and $\mathrm{Zn}$ (32 - 53\%; see Table 5) in the Pacific blue shrimp from the farm of St Vincent. The related distributions are in good agreement with the results reported by Keteles and Fleeger (2001). This observation was somewhat expected as these cations are known to be able to either substitute $\mathrm{Ca}$ in the cuticular $\mathrm{CaCO}_{3}$ (i.e., $\mathrm{Mn}$; Tu et al., 2008) or adsorb and bind strongly to the cuticle constituents (e.g., Rodriguez y Baena, 2006a, 2008). However, it was quite surprising to note that both experimental and field observations indicated that $\mathrm{Ag}$ and, secondarily, Cd were quite poorly associated with the shrimp cuticle. Indeed, Ag is well known to be a particlereactive element (Sañudo-Wilhelmy and Flegal, 1992; Metian and Warnau, 2008) and would thus be expected to bind in significant proportion onto the cuticle.

Our field and laboratory observations indicated that a significant proportion (20 $45 \%$ ) of $\mathrm{As}, \mathrm{Co}, \mathrm{Cr}, \mathrm{Cu}, \mathrm{Ni}$ and $\mathrm{Zn}$ was associated with the abdominal muscle of $L$. stylirostris. In terms of element concentrations measured in shrimp from the field, the NewCaledonia Pacific blue shrimp displayed metal and metalloid levels falling generally within the range of concentrations reported for the same, or closely related species, from other Pacific areas (Table 6). This was also true for elements which occur in high levels in New Caledonian laterites ( $\mathrm{Co}, \mathrm{Cr}, \mathrm{Ni}$ and $\mathrm{Mn})$. This suggests that 1) these elements are not 
particularly bioavailable to the shrimp when the organisms are in their aquaculture habitat (Metian et al., 2008a) and/or 2) the New Caledonian blue shrimp could have developed physiological strategies to regulate its body concentrations of these metals (White and Rainbow, 1984).

The element concentrations measured in the abdominal muscle of $L$. stylirostris were used to carry out a preliminary risk assessment for the human consumer in a similar way as those done by Frías-Espericueta et al. (2007) for the Pacific blue shrimp from the Gulf of California and by Metian et al. (2008a) for the scallop Comptopallium radula from New Caledonia. To do so, metal and metalloid concentrations measured in the shrimp abdominal muscle (alone or combined with other organs or tissues that can be eaten along) were confronted to maximum thresholds recommended by international organisations (FAO, WHO). Computations indicated that for any element considered consumption of shrimp did not present any significant risk. Indeed, in the "worse" situation (related to arsenic), the number of shrimp to be eaten in a single week by a 50-kg adult was > 180 to reach the WHO maximum recommended weekly intake.

\section{Conclusion}

The present laboratory and field study showed that the 9 metalloid and metals considered are mainly bioaccumulated, detoxified and/or stored in the digestive system (hepatopancreas and intestine) of L. stylirostris and are not highly bioaccumulated in its abominal muscle (i.e. the main edible part). Laboratory experiments have also shown that metals bioaccumulated by the shrimp (either via water or via the food) were relatively poorly retained in its tissues and that moulting can contribute substantially to metal depuration (mainly for $\mathrm{Co}, \mathrm{Cr}$, and, to a lesser extent, $\mathrm{Zn}$ ). With regards to the relatively 
low element concentrations measured in the abdominal muscle, no significant seafood safety problem could be identified for the elements examined. This is a particularly important observation in the context of the metalliferous environment of New Caledonia (Ambatsian et al., 1997; Mugnier et al., 2001), as it suggests that metals typically found in New Caledonia soils are poorly bioavailable to the farmed Pacific blue shrimp.

\section{Acknowledgements}

Authors thank the Ifremer Station of St Vincent, New Caledonia for providing the organisms, O. Cotret (IAEA-MEL) for skilful technical assistance and A.G.J. Tacon (Aquatic Farms Ltd, Hawaii) for critical reading of a previous version of the manuscript. MW is an Honorary Senior Research Associate of the National Fund for Scientific Research (NFSR, Belgium) and holds a 2008 Invited Expert position at LIENSs (CNRS-Université de La Rochelle), supported by the Conseil Régional de Poitou-Charente. This work was supported by the IAEA, the French PNEC Programme (Chantier "Nouvelle-Calédonie"), IRD and the French GIP Seine-Aval (PhD grant to $\mathrm{MM})$. The IAEA is grateful for the support provided to its Marine Environment Laboratories by the Government of the Principality of Monaco.

\section{References}

Ambatsian, P., Fernex, F., Bernat, M., Parron, C., Lecolle, J., 1997. High metal inputs to closed seas: the New Caledonia lagoon. Journal of Geochemical Exploration 59, 59-74.

Arruda-Freire, C., Campbell-McNamara, J., 1995. Fine structure of the gills of the fresh-water shrimp Macrobrachium olfersii (Decapoda): effect of acclimation to high salinity medium and evidence for involvement of the lamellar septum in ion uptake. Journal of Crustacean Biology 15, 103-116. 
Bendell-Young, L.I., 1994. Comparison of metal concentrations in the fore and hindguts of the crayfish Cambarus bartoni and Orconectes virilis and implications regarding metal absorption efficiencies. Bulletin of Environmental Contamination and Toxicology 53, $844-851$.

Berthet, B., Amiard, J.C., Amiard-Triquet, C., Martoja, R., Jeantet, A.Y., 1992. Bioaccumulation, toxicity and physico-chemical speciation of silver in bivalve molluscs: ecotoxicological and health consequences. Science of the Total Environment 125, 97-122.

Bianchini, A., Playle, R.C., Wood, C.M., Walsh, P.J., 2007. Short-term silver accumulation in tissues of three marine invertebrates: shrimp Penaeus duorarum, sea hare Aplysia californica, and sea urchin Diadema antillarum. Aquatic Toxicology 84, 182-189.

Boudjenoun, R., Teyssié, J.L., Rodriguez y Baena, A., Fowler, S.W., Warnau, M., 2007. Lead bioaccumulation in the Mediterranean mussel Mytilus galloprovincialis. Rapport de la Commission internationale de la Mer Méditerranée 38, 237.

Bruland, K.W., 1983. Trace elements in seawater. In: Riley, J.P., Chester, R. (Eds) Chemical oceanography, Vol. 8. Academic Press, pp. 157-220.

Buchanan, J.B., Brown, B.E., Coombs, T.L., Pine, B.J.S., Allen, J.A., 1980. The accumulation of ferric iron in the guts of some spatangoid echinoderms. Journal of Marine Biology Association UK 60, 631-640.

Cascorbi, A., 2007. Wild-caught warmwater shrimp (Infraorder Penaeus-the Penaeid shrimps). Seafood Watch, Seafood Report, Monterey Bay Aquarium.

Chouvelon, T., Warnau, M., Churlaud, C., Bustamante, M., 2009. Hg concentrations and related risk assessment in coral reef crustaceans, molluscs and fish from New Caledonia. Environmental Pollution 157, 331-340. 
Dall, W., Moriarty, D.J., 1983. Functional aspects of nutrition and digestion. In: Mantel, L.H.

(Ed) The biology of Crustacea, internal anatomy and physiological regulation. Academic Inc., NewYork, pp. 215-261.

Dalvi, A.D., Bacon, W.G., Osborne, R.C., 2004. The past and the future of nickel laterites. PDAC 2004 International Convention, Trade Show \& Investors Exchange.

Danis, B., Wantier, P., Flammang, R., Dutrieux, S., Dubois, P., Warnau, M., 2004. Contaminant levels in sediment and asteroids (Asterias rubens, Echinoderm) from the Belgian coast and Scheldt estuary: polychlorinated biphenyls and metals. Science of the Total Environment 333, 149-165.

Eisler, R., 1981. Trace metal concentrations in marine organisms. Pergamon Press, Inc., Elmsford, New York.

FAO, 2007. The state of world fisheries and aquaculture. FAO Fisheries and Aquaculture Department, FAO, Rome.

FAO, 2008. ProdSTAT: livestock (primary and processed), FAOSTAT, FAO. Rome (http://faostat.fao.org).

Frías-Espericueta, M.G., Izaguirre-Fierro, G., Valenzuela-Quiñonez, F., Osuna-López, J.I., Voltolina, D., López-López, G., Muy-Rangel, M.D., Rubio-Castro, W., 2007. Metal content of the Gulf of California blue shrimp Litopenaeus stylirostris (Stimpson). Bulletin of Environmental Contamination and Toxicology 79, 214-217.

Gibson, R., Barker, P.L., 1979. The decapod hepatopancreas. Oceanography and Marine Biology Annual Reviews 17, 285-346.

GFA, 2006. Groupement des Fermes Aquacoles (GFA). Rapports d'activité annuels.

Hédouin, L., Metian, M., Teyssié, J.-L., Fowler, S.W., Fichez, R., Warnau, M., 2006. Allometric relationships in the bioconcentration of heavy metals by the edible tropical clam Gafrarium tumidum. Science of the Total Environment 366, 154-163. 
Hédouin, L., Pringault, O., Metian, M., Bustamante, P., Warnau, M., 2007. Nickel bioaccumulation in bivalves from the New Caledonia lagoon: Seawater and food exposure. Chemosphere 66, 1449-1457.

Hédouin, L., Bustamante, P., Churlaud, C., Pringault, O., Fichez, R., Warnau, M., 2009. Trends in concentrations of selected metalloid and metals in two bivalves from the SW lagoon of New Caledonia. Ecotoxicology and Environmental Safety 72, 372-381

Jangoux, M., 1982. Digestive systems: Asteroidea. In: Jangoux, M., Lawrence, J.M. (Eds) Echinoderm nutrition. Balkema, Rotterdam, pp. 235-272.

JECFA, 2006. JECFA Evaluations - Cadmium. TRS 930-JECFA 64/26.

JECFA, 2008. http://www.inchem.org/pages/jecfa.html (accessed on 4 April 2008)

Keteles, K.A., Fleeger, J.W., 2001. The contribution of ecdysis to the fate of copper, zinc, and cadmium in grass shrimp, Palaemontes pugio Holthius. Marine Pollution Bulletin 42, 1397-1402.

Labonne, M., Morize, E., Kulbicki, M., Ponton, D., Marec, L., 2008. Otolith chemical signature and growth of Chaetodon speculum in coastal areas of New Caledonia. Estuarine, Coastal and Shelf Science 78, 493-504.

Labrosse, P., Fichez, R., Farman, R., Adams, T., 2000. New Caledonia in: Sheppard, C.R.C. (Ed.), Seas at the Millenium: an environmental evaluation. Pergamon, Amsterdam, pp. $723-736$.

Luoma, S.N., Rainbow, P.S., 2005. Why is metal bioaccumulation so variable? Biodynamics as a unifying concept. Environmental Science and Technology 39, 1921-1931.

Méndez, L., Racotta, I.S., Acosta, B., Rodriguez-Jaramillo, C., 2001. Mineral concentration in tissues during ovarian development of the white shrimp Penaeus vannamei (Decapoda: Penaeidae). Marine Biology 138, 687-692. 
Metian, M., Bustamante, P., Oberhänsli, F., Teyssié, J.L., Warnau, M., 2007. Interspecific comparison of Cd bioaccumulation in European Pectinidae (Chlamys varia and Pecten maximus). Journal of Experimental Marine Biology and Ecology 353, 58-67.

Metian, M., Bustamante, P., Hédouin, L., Warnau, M., 2008a. Accumulation of nine metals and one metalloid in the tropical scallop Comptopallium radula from coral reefs in New Caledonia. Environmental Pollution 152, 543-552.

Metian, M., Giron, E., Borne, V., Hédouin, L., Teyssié, J.L., Warnau, M., 2008b. The brown alga Lobophora variegata, a bioindicator species for surveying metal contamination in tropical marine environments. Journal of Experimental Marine Biology and Ecology 362, $49-54$.

Metian, M., Warnau, M., Cosson, R., Bustamante, P., 2008c. Bioaccumulation and detoxification processes of $\mathrm{Hg}$ in the king scallop Pecten maximus: field and laboratory investigations. Aquatic Toxicology 90, 204-213.

Metian, M., Warnau, M., 2008. The tropical brown alga Lobophora variegata: a prospective bioindicator for Ag contamination in tropical coastal waters. Bulletin of Environmental Contamination and Toxicology 81, 455-458.

Mugnier, C., Magand, O., Breau, L., Fernandez, J.M., Lemonnier, H., 2001. Métaux et crevettes d'élevage en Nouvelle Calédonie. Travail préliminaire d'analyse de la teneur en métaux chez les crevettes et le sédiment. Fiche biotechnique $\mathrm{n}^{\circ}$ 2001-02, Laboratoire d'Aquaculture de Nouvelle Calédonie - Station de Saint Vincent, 18 p.

Nunez-Nogueira, G., Rainbow, P.S., Smith, B.D., 2006. Assimilation efficiency of zinc and cadmium in the decapod crustacean Penaeus indicus. Journal of Experimental Marine Biology and Ecology 332, 75-83. 
Paez-Osuna, F., Ruiz-Fernandez, C., 1995a. Comparative bioaccumulation of trace metals in Penaeus stylirostris in estuarine and coastal environments. Estuarine, Coastal and Shelf Science 40, 35-44.

Paez-Osuna, F., Ruiz-Fernandez, C., 1995b. Trace metals in the Mexican shrimp Penaeus vannamei from estuarine and marine environments. Environmental Pollution 87, 243-247.

Paez-Osuna, F., Tron-Mayen, L., 1996. Concentration and distribution of heavy metals in tissues of wild and farmed shrimp Penaeus vannamei from the Northwest Coast of Mexico. Environment International 22, 443-450.

Rainbow, P.S., 1998. Phylogeny of trace metal accumulation in crustaceans. In: Langston, W.J., Bebianno, M. (Eds). Metal metabolism in aquatic environments. Chapman and Hall, London, pp. 285-319.

Rainbow, P.S., 2002. Trace metal concentrations in aquatic invertebrates: why and so what? Environmental Pollution 120, 497-507.

Rainbow, P.S., Poirier, L., Smith, B.D., Brix, K.V., Luoma S.N., 2006a. Trophic transfer of trace metals: subcellular compartmentalization in a polychaete and assimilation by a decapod crustacean. Marine Ecology Progress Series 308, 91-100.

Rainbow, P.S., Poirier, L., Smith, B.D., Brix, K.V., Luoma S.N., 2006b. Trophic transfer of trace metals from the polychaete worm Nereis diversicolor to the polychaete $N$. virens and the decapod crustacean Palaemonetes varians. Marine Ecology Progress Series 321, $167-$ 181.

Rodriguez y Baena, A.M., Metian, M., Teyssié, J.L., De Broyer, C., Warnau, M., $2006 a$. Experimental evidence for ${ }^{234} \mathrm{Th}$ bioaccumulation in three Antarctic crustaceans: potential implications in particle flux studies. Marine Chemistry 100, 354-365. 
Rodriguez y Baena, A.M., Miquel, J.C., Masqué, P., Povinec, P., La Rosa, J., 2006b. A single vs. double spike approach to improve the accuracy of ${ }^{234} \mathrm{Th}$ measurements in smallvolume seawater samples. Marine Chemistry 100, 269-281.

Rodriguez y Baena, A.M., Fowler, S.W., Warnau, M., 2008. Could krill schools significantly bias ${ }^{234}$ Th-based flux models? Limnology and Oceanography 53, 1186-1191.

Ruelas-Inzunza, J., Paez-Osuna, F., 2004. Distribution and concentration of trace metals in tissues of three penaeid shrimp species from Altata-Ensenada del Pabellon Lagoon (S.E. Gulf of California). Bulletin of Environmental Contamination and Toxicology 72, 452459.

Sañudo-Wilhelmy, S.A., Flegal, R., 1992. Anthropogenic silver in the southern California bight: a new tracer of sewage in coastal waters. Environmental Science and Technology $26,2147-2151$.

Temara, A., Ledent, G., Warnau, M., Paucot, H., Jangoux, M., Dubois, P., 1996. Experimental cadmium contamination of Asterias rubens (Echinodermata). Marine Ecology Progress Series 140, 83-90.

Tu, N.P.C., Ha, N.N., Ikemoto, T., Tuyen, B.C., Tanabe, S., Takeuchi, I., 2008. Regional variations in trace element concentrations in tissues of black tiger shrimp Penaeus monodon (Decapoda: Penaeidae) from South Vietnam. Marine Pollution Bulletin 57, 858866.

Wallace, W.G., Lopez, G.R., Levington, J.S., 1998. Cadmium resistance in an oligochaete and its effect on cadmium trophic transfer to an omnivorous shrimp. Marine Ecology Progress Series 172, 225-237.

Warnau, M., Bustamante, P., 2007. Radiotracer techniques: a unique tool in marine ecotoxicological studies. Environmental Bioindicators 2, 217-218. 
Warnau, M., Teyssié, J.L., Fowler S.W., 1996a. Biokinetics of selected heavy metals and radionuclides in the common Mediterranean echinoid Paracentrotus lividus: seawater and food exposures. Marine Ecology Progress Series 141, 83-94.

Warnau, M., Fowler, S.W., Teyssié, J.L., 1996b. Biokinetics of selected heavy metals and radionuclides in two marine macrophytes: the seagrass Posidonia oceanica and the alga Caulerpa taxifolia. Marine Environmental Research 41, 343-362.

Warnau, M., Fowler, S.W., Teyssié, J.L., 1999. Biokinetics of radiocobalt in the asteroid Asterias rubens (Echinodermata): sea water and food exposures. Marine Pollution Bulletin 39, 159-164.

Warnau, M., Jangoux, M., 1999. In vitro and in vivo investigations of the excretory function of the rectal caeca in the asteroid Asterias rubens (Echinodermata). Comparative Biochemistry and Physiology 123A, 263-267.

White, S.L., Rainbow, P.S., 1984. Regulation of zinc concentration by Palaemon elegans (Crustacea: Decapoda): zinc flux and effects of temperature, zinc concentration and moulting. Marine Ecology Progress Series 16, 135-147.

WHO, 1989. Environmental Health Criteria 18: Arsenic. World Health Organization, Geneva. Zar, J.H., 1996. Biostatistical analysis. Upper Saddle River, New Jersey. 
Table 1. Litopenaeus stylirostris. Parameters (mean \pm ASE, $n=20$ ) of the whole-body uptake and/or depuration kinetics of 5 metal radiotracers in the Pacific blue shrimp exposed to the radiotracers via seawater (A) and via the food (B).

Uptake parameters: $\mathrm{CF}_{\mathrm{ss}}$ : concentration factor at steady state; $\mathrm{k}_{\mathrm{u}}$ : uptake rate constant $\left(\mathrm{d}^{-1}\right)$; $\mathrm{L}$ and $\mathrm{E}$ : linear $\left[\mathrm{CF}_{\mathrm{t}}=\mathrm{k}_{\mathrm{u}} \mathrm{t}\right]$ and exponential $\left[\mathrm{CF}_{\mathrm{t}}=\right.$ $\left.\mathrm{CF}_{\mathrm{ss}}\left(1-\mathrm{e}^{-\mathrm{k}_{\mathrm{e}} \mathrm{t}}\right)\right]$ model, respectively.

Depuration parameters: $\mathrm{A}_{0 \mathrm{~s}}$ and $\mathrm{A}_{01}$ : activity (\%) lost according to the short-and the long-lived exponential component, respectively; $\mathrm{T}_{\mathrm{b} / 2}$ :

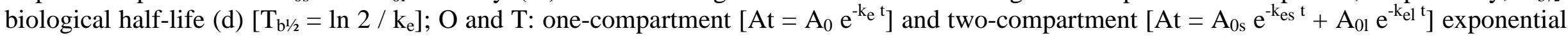
model, respectively.

ASE: asymptotic standard error; $r^{2}$ : determination coefficient of kinetics.

\begin{tabular}{|c|c|c|c|c|c|c|c|c|c|c|c|}
\hline \multirow[b]{2}{*}{ Experiment } & \multicolumn{5}{|c|}{ Uptake } & \multicolumn{6}{|c|}{ Depuration } \\
\hline & Metal & Model & $\mathrm{CF}_{\mathrm{ss}} \pm \mathrm{ASE}$ & $\mathrm{k}_{\mathrm{u}} \pm \mathrm{ASE}$ & $\mathrm{r}^{2}$ & Model & $\mathrm{A}_{0 \mathrm{~s}} \pm \mathrm{ASE}$ & $\mathrm{T}_{\mathrm{b}^{1 / 2 \mathrm{~S}}} \pm \mathrm{ASE}$ & $\mathrm{A}_{01} \pm \mathrm{ASE}$ & $\mathrm{T}_{\mathrm{b}^{1 / 2} \mathrm{l}} \pm \mathrm{ASE}$ & $\mathrm{r}^{2}$ \\
\hline \multirow{5}{*}{$\begin{array}{l}\text { A. Seawater } \\
\text { exposure }\end{array}$} & ${ }^{110 m} \mathrm{Ag}$ & $\mathrm{L}$ & - & $3.58 \pm 0.07^{\mathrm{d}}$ & 0.78 & $\mathrm{O}$ & - & - & $94 \pm 2^{d}$ & $20 \pm 1^{\mathrm{d}}$ & 0.69 \\
\hline & ${ }^{109} \mathrm{Cd}$ & $\mathrm{L}$ & - & $0.81 \pm 0.01^{\mathrm{d}}$ & 0.86 & $\mathrm{~T}$ & $72 \pm 29^{a}$ & $8 \pm 4^{\mathrm{a}}$ & $29 \pm 29$ & 796 & 0.84 \\
\hline & ${ }^{57} \mathrm{Co}$ & $\mathrm{E}$ & $6.2 \pm 0.3^{d}$ & $2.23 \pm 0.67^{c}$ & 0.32 & $\mathrm{~T}$ & $88 \pm 6^{d}$ & $2.2 \pm 0.2^{\mathrm{d}}$ & $9 \pm 7$ & $18 \pm 16$ & 0.94 \\
\hline & ${ }^{51} \mathrm{Cr}$ & $\mathrm{E}$ & $3.9 \pm 0.7^{d}$ & $0.31 \pm 0.05^{\mathrm{d}}$ & 0.32 & $\mathrm{~T}$ & $51 \pm 5^{\mathrm{d}}$ & $0.5 \pm 0.2^{b}$ & $49 \pm 3^{d}$ & $152 \pm 89$ & 0.37 \\
\hline & ${ }^{65} \mathrm{Zn}$ & $\mathrm{E}$ & $53.6 \pm 0.7^{d}$ & $4.84 \pm 0.34^{\mathrm{c}}$ & 0.74 & $\mathrm{~T}$ & $39 \pm 4^{\mathrm{d}}$ & $1.9 \pm 0.5^{\mathrm{d}}$ & $57 \pm 5^{d}$ & $35 \pm 6^{d}$ & 0.85 \\
\hline \multirow{5}{*}{$\begin{array}{l}\text { B. Food } \\
\text { exposure }\end{array}$} & ${ }^{110 \mathrm{~m}} \mathrm{Ag}$ & - & - & - & - & $\mathrm{O}$ & - & - & $101 \pm 2^{d}$ & $10.8 \pm 0.5^{\mathrm{d}}$ & 0.79 \\
\hline & ${ }^{109} \mathrm{Cd}$ & - & - & - & - & $\mathrm{T}$ & $23 \pm 6^{b}$ & $1.7 \pm 0.6^{\mathrm{b}}$ & $77 \pm 5^{d}$ & $7 \pm 1^{d}$ & 0.88 \\
\hline & ${ }^{57} \mathrm{Co}$ & - & - & - & - & $\mathrm{O}$ & - & - & $100 \pm 2^{d}$ & $1.2 \pm 0.2^{\mathrm{d}}$ & 0.94 \\
\hline & ${ }^{51} \mathrm{Cr}$ & - & - & - & - & $\mathrm{T}$ & $46 \pm 5^{d}$ & $0.7 \pm 0.2^{c}$ & $54 \pm 4^{\mathrm{d}}$ & $32 \pm 5^{d}$ & 0.49 \\
\hline & ${ }^{65} \mathrm{Zn}$ & - & - & - & - & $\mathrm{T}$ & $62 \pm 3^{d}$ & $0.8 \pm 0.1^{\mathrm{d}}$ & $39 \pm 2^{d}$ & $19 \pm 2^{d}$ & 0.87 \\
\hline
\end{tabular}

Probability -p- of the parameter estimation: ${ }^{a} p<0.05 .{ }^{b} p<0.01 .{ }^{c} p<0.001 .{ }^{d} p<0.0001$ 
Table 2. Litopenaeus stylirostris. Radiotracer distribution (\%; mean $\pm \mathrm{SD}, \mathrm{n}=3$ ) among the tissues and organs of the Pacific blue shrimp after 4 and $43 \mathrm{~d}$ of depuration following seawater exposure and after $39 \mathrm{~d}$ following radiolabelled food ingestion.

\begin{tabular}{|c|c|c|c|c|c|}
\hline & ${ }^{110 m} \mathrm{Ag}$ & ${ }^{109} \mathrm{Cd}$ & ${ }^{57} \mathrm{Co}$ & ${ }^{51} \mathrm{Cr}$ & ${ }^{65} \mathrm{Zn}$ \\
\hline Seawater experiment & \multicolumn{4}{|c|}{$4 d$ of depuration } & \\
\hline cephalothorax & $20 \pm 3$ & $52 \pm 9$ & $38 \pm 14$ & $47 \pm 16$ & $51 \pm 9$ \\
\hline exoskeleton & $<1$ & $5 \pm 1$ & $8 \pm 6$ & $9 \pm 3$ & $9 \pm 5$ \\
\hline intestine & $<1$ & $1 \pm 0.1$ & $1 \pm 0.3$ & $3 \pm 0.1$ & $1 \pm 0.2$ \\
\hline hepatopancreas & $79 \pm 3$ & $39 \pm 10$ & $50 \pm 20$ & $30 \pm 16$ & $9 \pm 5$ \\
\hline \multirow[t]{2}{*}{ muscle } & $1 \pm 0.1$ & $4 \pm 1$ & $4 \pm 1$ & $11 \pm 2$ & $31 \pm 4$ \\
\hline & \multicolumn{4}{|c|}{43 d of depuration } & \\
\hline cephalothorax & $14 \pm 5$ & $73 \pm 3$ & $38 \pm 7$ & $<$ d.l. & $41 \pm 1$ \\
\hline exoskeleton & $2 \pm 1$ & $8 \pm 1$ & $26 \pm 2$ & $<$ d.l. & $8 \pm 1$ \\
\hline intestine & $3 \pm 1$ & $1 \pm 1$ & $7 \pm 1$ & $<$ d.l. & $<1$ \\
\hline hepatopancreas & $78 \pm 7$ & $11 \pm 3$ & $10 \pm 1$ & $<$ d.l. & $5 \pm 1$ \\
\hline muscle & $2 \pm 1$ & $7 \pm 2$ & $19 \pm 4$ & $<\mathrm{d} .1$. & $45 \pm 2$ \\
\hline \multicolumn{2}{|l|}{ Feeding experiment } & \multicolumn{2}{|c|}{39 d of depuration } & & \\
\hline cephalothorax & $21 \pm 11$ & $66 \pm 18$ & $33 \pm 3$ & $<$ d.l. & $42 \pm 4$ \\
\hline exoskeleton & $6 \pm 3$ & $2 \pm 0.2$ & $18 \pm 1$ & $<\mathrm{d} .1$. & $9 \pm 1$ \\
\hline intestine & $7 \pm 4$ & $1 \pm 0.1$ & $15 \pm 3$ & $<\mathrm{d} .1$. & $<1$ \\
\hline hepatopancreas & $58 \pm 21$ & $30 \pm 18$ & $14 \pm 1$ & $<\mathrm{d} .1$. & $6 \pm 1$ \\
\hline muscle & $7 \pm 3$ & $2 \pm 1$ & $20 \pm 2$ & $<$ d.l. & $44 \pm 2$ \\
\hline
\end{tabular}


Table 3. Litopenaeus stylirostris. Activity concentration $\left(\mathrm{Bq}^{-1}\right.$ wet wt; mean $\left.\pm \mathrm{SD}, \mathrm{n}=3\right)$ of radiotracers in the body compartments of the Pacific blue shrimp during the depuration period following seawater and food exposures.

\begin{tabular}{|c|c|c|c|c|c|c|}
\hline & Weight (g) & ${ }^{110 \mathrm{~m}} \mathrm{Ag}$ & ${ }^{109} \mathrm{Cd}$ & ${ }^{57} \mathrm{Co}$ & ${ }^{51} \mathrm{Cr}$ & ${ }^{65} \mathrm{Zn}$ \\
\hline \multicolumn{2}{|c|}{ Seawater experiment } & \multicolumn{4}{|c|}{$4 d$ of depuration } & \\
\hline cephalothorax & $2.61 \pm 0.48$ & $6.31 \pm 1.27$ & $56.8 \pm 7.2$ & $2.22 \pm 0.16$ & $3.76 \pm 1.34$ & $20.2 \pm 2.9$ \\
\hline exoskeleton & $0.71 \pm 0.21$ & $<0.01$ & $18.2 \pm 2.9$ & $1.57 \pm 1.01$ & $2.71 \pm 0.89$ & $13.5 \pm 8.9$ \\
\hline intestine & $0.04 \pm 0.02$ & $1.83 \pm 0.86$ & $88.8 \pm 52.7$ & $2.77 \pm 1.41$ & $20.2 \pm 10.3$ & $24.9 \pm 20.1$ \\
\hline hepatopancreas & $0.25 \pm 0.05$ & $276 \pm 99$ & $468 \pm 177$ & $35.5 \pm 24.5$ & $23.6 \pm 11.3$ & $39.5 \pm 23.6$ \\
\hline \multirow[t]{2}{*}{ muscle } & $2.79 \pm 0.92$ & $<0.01$ & $4.14 \pm 1.73$ & $0.21 \pm 0.02$ & $0.82 \pm 0.02$ & $11.9 \pm 2.8$ \\
\hline & \multicolumn{6}{|c|}{43 d of depuration } \\
\hline cephalothorax & $2.75 \pm 0.17$ & $0.31 \pm 0.04$ & $31.3 \pm 3.72$ & $0.27 \pm 0.03$ & $<\mathrm{d} .1$. & $6.52 \pm 0.74$ \\
\hline exoskeleton & $1.17 \pm 0.58$ & $<0.01$ & $9.11 \pm 1.41$ & $0.54 \pm 0.31$ & $<$ d.l. & $3.39 \pm 0.68$ \\
\hline intestine & $0.02 \pm 0.01$ & $12.7 \pm 5.55$ & $86.3 \pm 41.1$ & $8.79 \pm 3.40$ & $<\mathrm{d} .1$. & $9.05 \pm 7.83$ \\
\hline hepatopancreas & $0.33 \pm 0.08$ & $17.0 \pm 9.85$ & $38.2 \pm 9.2$ & $0.62 \pm 0.25$ & $<\mathrm{d} .1$. & $6.82 \pm 0.96$ \\
\hline muscle & $3.47 \pm 0.25$ & $<0.01$ & $2.18 \pm 0.43$ & $0.11 \pm 0.05$ & $<\mathrm{d} .1$. & $5.75 \pm 0.71$ \\
\hline \multicolumn{2}{|c|}{ Feeding experiment } & \multicolumn{4}{|c|}{39 d of depuration } & \\
\hline cephalothorax & $3.74 \pm 0.31$ & $0.06 \pm 0.02$ & $18.4 \pm 9.2$ & $0.09 \pm 0.02$ & $<$ d.l. & $11.4 \pm 1.4$ \\
\hline exoskeleton & $1.32 \pm 0.11$ & $<0.01$ & $1.44 \pm 0.77$ & $0.14 \pm 0.04$ & $<\mathrm{d} .1$. & $6.73 \pm 0.59$ \\
\hline intestine & $0.02 \pm 0.01$ & $4.28 \pm 2.88$ & $52.9 \pm 32.6$ & $8.02 \pm 3.86$ & $<\mathrm{d} .1$. & $8.40 \pm 2.21$ \\
\hline hepatopancreas & $0.39 \pm 0.12$ & $1.97 \pm 0.95$ & $74.0 \pm 55.7$ & $0.38 \pm 0.05$ & $<\mathrm{d} .1$. & $14.7 \pm 1.1$ \\
\hline muscle & $4.51 \pm 0.62$ & $<0.01$ & $0.41 \pm 0.29$ & $0.05 \pm 0.01$ & $<\mathrm{d} .1$. & $9.91 \pm 0.83$ \\
\hline
\end{tabular}


Table 4. Litopenaeus stylirostris. Element concentrations $\left(\mu \mathrm{g} \mathrm{g}^{-1}\right.$ dry wt; mean $\pm \mathrm{SD}, \mathrm{n}=12$ ) in tissues and organs of the Pacific blue shrimp collected in the aquaculture farm of Saint-Vincent, SW New Caledonia.

\begin{tabular}{cccccccccc}
\hline & $\mathbf{A g}$ & $\mathbf{A s}$ & $\mathbf{C d}$ & $\mathbf{C o}$ & $\mathbf{C r}$ & $\mathbf{C u}$ & $\mathbf{M n}$ & $\mathbf{N i}$ & $\mathbf{Z n}$ \\
\hline Cephalothorax & $<0.01$ & $8.6 \pm 2.1$ & $0.24 \pm 0.11$ & $0.27 \pm 0.02$ & $0.9 \pm 0.6$ & $129 \pm 16$ & $21 \pm 5$ & $1.5 \pm 0.5$ & $74 \pm 6$ \\
Exoskeleton & $<0.01$ & $7.3 \pm 0.9$ & $0.02 \pm 0.01$ & $0.20 \pm 0.06$ & $3.7 \pm 3.3$ & $158 \pm 19$ & $18 \pm 8$ & $4.6 \pm 3.7$ & $81 \pm 14$ \\
Hepatopancreas & $1.8 \pm 1.3$ & $22 \pm 12$ & $6.5 \pm 3.8$ & $3.1 \pm 1.7$ & $2.5 \pm 2.8$ & $1097 \pm 726$ & $64 \pm 41$ & $16 \pm 22$ & $269 \pm 158$ \\
Intestine & $0.04 \pm 0.04$ & $18 \pm 18$ & $0.5 \pm 0.4$ & $1.2 \pm 1.6$ & $12 \pm 17$ & $118 \pm 118$ & $50 \pm 36$ & $21 \pm 14$ & $158 \pm 92$ \\
Muscle & $<0.01$ & $6.4 \pm 1.1$ & $<0.01$ & $0.03 \pm 0.02$ & $1.8 \pm 2.0$ & $40 \pm 10$ & $1.8 \pm 1.9$ & $1.7 \pm 1.4$ & $70 \pm 5$ \\
\hline
\end{tabular}


Table 5. Litopenaeus stylirostris. Element distribution (\%; mean $\pm \mathrm{SD}, \mathrm{n}=12)$ among the tissues and organs of the Pacific blue shrimp collected in the aquaculture farm of Saint-Vincent, SW New Caledonia.

\begin{tabular}{cccccccccc}
\hline & Ag & As & Cd & Co & Cr & Cu & Mn & Ni & $\mathbf{Z n}$ \\
\hline Cephalothorax & 0 & $28 \pm 4$ & $57 \pm 18$ & $40 \pm 6$ & $10 \pm 8$ & $31 \pm 5$ & $44 \pm 5$ & $12 \pm 5$ & $22 \pm 4$ \\
Exoskeleton & 0 & $28 \pm 3$ & $4 \pm 3$ & $38 \pm 7$ & $53 \pm 11$ & $43 \pm 8$ & $44 \pm 8$ & $49 \pm 13$ & $32 \pm 6$ \\
Hepatopancreas & $98 \pm 3$ & $2 \pm 1$ & $37 \pm 25$ & $11 \pm 9$ & $1 \pm 0.1$ & $7 \pm 6$ & $3 \pm 2$ & $4 \pm 4$ & $2 \pm 2$ \\
Intestine & $2 \pm 3$ & 0 & $1 \pm 1$ & $2 \pm 4$ & $2 \pm 3$ & 0 & $1 \pm 2$ & $2 \pm 2$ & $1 \pm 2$ \\
Muscle & 0 & $44 \pm 9$ & $1 \pm 1$ & $9 \pm 6$ & $34 \pm 12$ & $19 \pm 10$ & $8 \pm 6$ & $33 \pm 11$ & $43 \pm 10$ \\
\hline
\end{tabular}


Table 6. Comparison of metal levels $\left(\mu \mathrm{g} \mathrm{g}^{-1}\right.$ dry wt; mean $\pm \mathrm{SD}$ ) in the abdominal muscle of Litopenaeus stylirostris and Penaeus vannamei.

\begin{tabular}{|c|c|c|c|c|c|c|c|c|c|c|c|}
\hline & Ag & As & Cd & Co & $\mathbf{C r}$ & $\mathbf{C u}$ & $\mathbf{F e}$ & Mn & $\mathbf{N i}$ & $\mathbf{Z n}$ & Reference \\
\hline \multicolumn{12}{|l|}{ L. stylirostris } \\
\hline Juveniles & - & - & $0.44 \pm 0.12$ & $1.08 \pm 0.81$ & $0.7 \pm 0.4$ & $21 \pm 9$ & $133 \pm 32$ & $4.2 \pm 2.3$ & $1.7 \pm 1.2$ & $84 \pm 21$ & Paez-Osuna \& Ruiz-Fernandez (1995a) \\
\hline Adults & - & - & $0.61 \pm 0.40$ & $0.42 \pm 0.23$ & $0.3 \pm 0.2$ & $37 \pm 18$ & $41 \pm 22$ & $1.4 \pm 0.8$ & $0.7 \pm 0.2$ & $75 \pm 26$ & Paez-Osuna \& Ruiz-Fernandez (1995a) \\
\hline Adults & - & - & 0.66 & - & - & 25.4 & - & - & - & 58 & Frías-Espericueta et al. (2007) \\
\hline Sub-adults & $<0.01$ & $6.4 \pm 1.0$ & $<0.01$ & $0.03 \pm 0.02$ & $1.8 \pm 2.0$ & $40 \pm 10$ & - & $2 \pm 2$ & $1.7 \pm 1.4$ & $70 \pm 5$ & Present study \\
\hline \multicolumn{12}{|l|}{ P. vannamei } \\
\hline Juveniles & - & - & $0.53 \pm 0.35$ & $0.87 \pm 0.48$ & $1.6 \pm 1.6$ & $23 \pm 6$ & $201 \pm 120$ & $7.5 \pm 3.3$ & $1.3 \pm 0.5$ & $59 \pm 20$ & Paez-Osuna \& Ruiz-Fernandez (1995b) \\
\hline Adults & - & - & $0.77 \pm 0.01$ & $1.18 \pm 0.51$ & $0.8 \pm 0.1$ & $28 \pm 2$ & $54 \pm 9$ & $4.5 \pm 3.8$ & $0.8 \pm 0.1$ & $70 \pm 5$ & Paez-Osuna \& Ruiz-Fernandez (1995b) \\
\hline
\end{tabular}




\section{Captions to Figures}

3

4 Figure 1. Litopenaeus stylirostris. Uptake and depuration kinetics of 5 dissolved radiotracers $5 \quad\left({ }^{110 \mathrm{~m}} \mathrm{Ag},{ }^{109} \mathrm{Cd},{ }^{57} \mathrm{Co},{ }^{51} \mathrm{Cr}\right.$ and ${ }^{65} \mathrm{Zn}$ ) during a $24-\mathrm{d}$ exposure (Concentration factor; mean \pm $6 \mathrm{SD} ; \mathrm{n}=20$ ), then maintained for $43 \mathrm{~d}$ in non contaminated conditions (Remaining \% activity;

7 mean $\pm \mathrm{SD} ; \mathrm{n}=20$ ).

8

9

10 Figure 2. Litopenaeus stylirostris. Depuration kinetics (Remaining activity -\%-; mean \pm SD; n $11=20)$ of 5 radiotracers $\left({ }^{110 \mathrm{~m}} \mathrm{Ag},{ }^{109} \mathrm{Cd},{ }^{57} \mathrm{Co},{ }^{51} \mathrm{Cr}\right.$ and $\left.{ }^{65} \mathrm{Zn}\right)$ after a single feeding on 12 radiolabelled mussel flesh. 

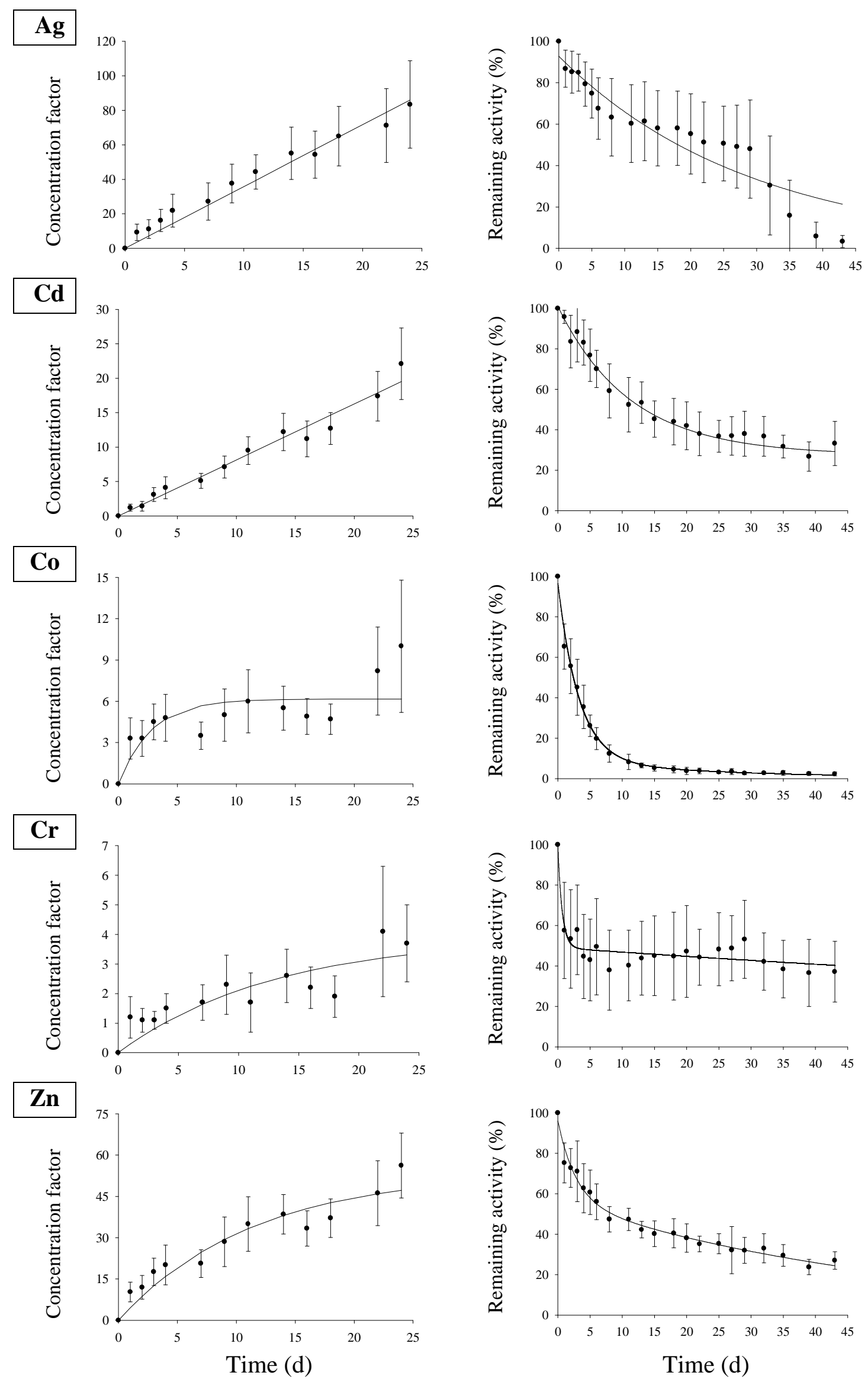

Figure 1 

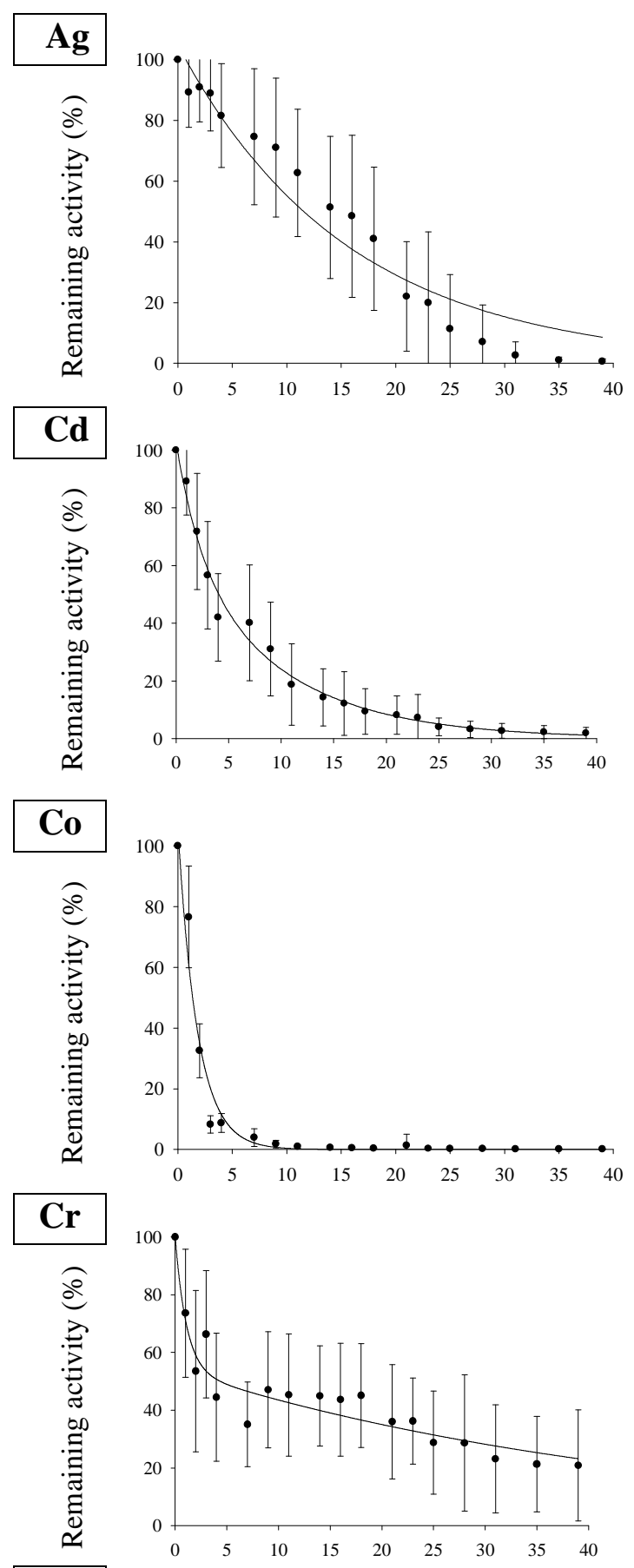

Zn

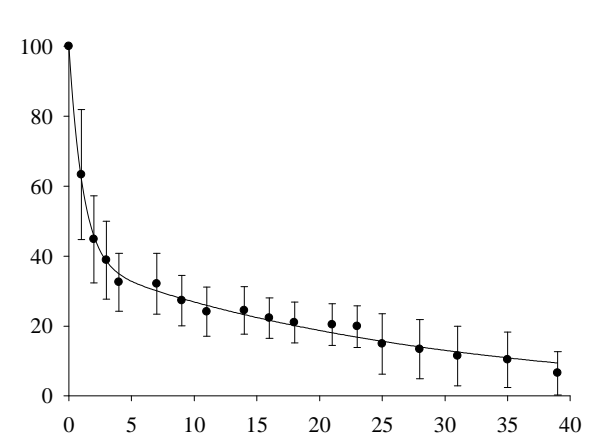

Time (d)

Figure 2. 